\title{
The Role of the Police in Law Enforcement During the Covid-19 Pandemic
}

\author{
Santi Wijaya ${ }^{1}$, Megawati Barthos ${ }^{2}$ \\ \{Shantywta06@gmail.com ${ }^{1}$,megawati_barthos@borobudur.ac.id ${ }^{2}$ \} \\ Universitas Borobudur, Jakarta, Indonesia ${ }^{1,2}$
}

\begin{abstract}
This paper presents the role of the Polices in enforcing the law during the Covid Pandemic Period. Through normative juridical research methods and literature studies, it was found that the police played a critical role during the COVID-19 pandemic, especially in law enforcement for violating health protocols and increasing crime. The role of the police in law enforcement is seen in the telegram of the National Police Chief as a strategic step to crack down on various crimes, both in the economic, cyber, and conventional fields.
\end{abstract}

Keywords: Police; Crime, Security; Covid 19 Pandemic

\section{Introduction}

As time goes by and the development of social civilization, the problems faced by society are increasingly complex. The problem complexity has a direct impact on all aspects of people's lives that can disturb the community, and there are demands to make changes and find solutions to stop the problems that occur.

Generally, the cause of social problems in society is due to a sense of incompatibility between desires and the reality that exists in the community, so that this condition gives rise to various dynamics that threaten the social order. Social problems are closely related to social values and social institutions. The problem is social because it is related to human relations and within the framework of the normative parts of culture and is called a problem because it is related to symptoms that disturb the continuity of society. Thus, social problems are related to social values concerning the moral aspect. It is a problem because the code of conduct is immoral, against the law, and destructive. Social problems arise from deficiencies in humans or social groups originating from economic, biological, biopsychological, and cultural factors.

According to Soerjono Soekanto, social problems are mismatches between cultural elements that endanger community groups.[1] Social problems are contextual, meaning that they occur in one place at a specific time. It may be that in one area, the social phenomena that arise are considered a problem, but in another, it is not. Sometimes it's a problem, but not in other times. Social problems emerge for various reasons, such as incompatibility between social values and social actions, minority interests precede the interests of the majority of society, social organizations cannot organize citizens to be harmonious. One of the social problems currently being faced by the Indonesian people and even the whole world is the outbreak of the Covid-19 or Corona Virus pandemic which every day takes the number of victims that continues to grow.[2] It is undeniable that the increasing outbreak of the Covid-19 
pandemic has affected the social and economic conditions in society and has even destroyed all joints of the country, from community activities to the economy and psychological disorders. This condition will directly impact the trend of increasing crime committed by the community. The increasing crime rate demands extra police work. Indonesia, which is currently heading for a new normal, makes the role of the National Police very crucial. Various efforts have been made by the government to reduce the impact of the COVID-19 pandemic.[3] However, the efforts made are not considered effectual enough. Economic growth that continues to slow down seems to have led the government to choose a new normal order as a temporary way out until a Covid-19 vaccine is found.

One thing that needs to be considered and becomes an important issue is the issue of national public security. The security and stability of a country must be guaranteed by the government, so that the people, individually, in groups, or as a whole, get peace and comfort in carrying out their daily activities. Security and stability assurance should be based on law, knowledge, and technology. Security and stability assurance based on law indicates that it is formulated in the legal system that applies in the country or internationally, as formulated in the form of laws, government regulations, and other legal procedures. Knowledge-based security and stability assurance means that dynamical efforts to develop stability and security are based on scientific principles. Assurance of technology-based security and stability means a dynamic attempt to build constancy and safety by utilizing technology and all its advances.

Empirical facts show the occurrence of mass layoffs caused by the Covid 19 pandemic. Mass layoffs have the potential to trigger crime in society. Anxiety arising from the termination of employment is a layoff concern for law enforcement officers.[4] Plus the policy of releasing prisoners by the government due to the spread of Covid 19 in the prison environment.[5] Anxiety in the community made the government make a policy to mobilize security forces, both from the Police and the TNI. In their duties, POLRI issues policies that must be obeyed by the community and the community will always be supervised by the POLRI to implement the policies that have been set.[6] It is in the context of protecting and guaranteeing security for the community. The Covid-19 pandemic also requires the Indonesian National Police to play a role in disease control efforts, educating the public and taking action against crimes that see the outbreak as an opportunity to commit various crimes.

Many pros and cons in society are related to the urgency of involving the Police in handling the Covid 19 Pandemic. People who agree, gave their appreciation for the government's actions in involving the Police in maintaining security and order in society. People who disagree, then argue that the Cops will cloud the atmosphere of security and order in the community. From this description, the question arises what is the role of the Police in the Covid-19 pandemic? This paper will further describe the strategic position of the Cops in maintaining security and order during the Covid-19 Pandemic.

\section{Methods}

This paper uses a normative juridical research method in a qualitative approach.[7] Data collection is carried out in the literature, by conducting a study of legislation, policies, and other literature related to the topic of the study discussed in this article.[8] Descriptive analysis is used in presenting data and discussions in the discussion so that it can be presented comprehensively and in-depth. 


\section{Discussion}

The word police comes from the Greek word "politea." At first, this word was used to refer to people who became citizens of Athens, then the meaning developed into a city and was used to refer to all city businesses. Because at that time, cities were independent states, which were also known as Polis, so Politea or Polis were defined as all state efforts and activities, including religious activities.

In its development, after the middle of Christ, the religion of Christ made progress and developed very widely. So the longer the religious affairs and activities became more and more so that they had special activities and needed to be held explicitly, at last, spiritual matters were excluded from the business of the Politea (State/City Police).

According to Article 1 point 1 of Law no. 2 of 2002 concerning the National Police,[9] it is expressed that "Police are on the whole matters identifying with the capacities and establishments of the police following legal guidelines." Scholars in the field of the police state that the word police has three meanings, namely:

1. Police as a function;

2. Police as a state organ;

3. Police as official/duty

According to Article 2 of Law no. 2 of 2002 concerning the National Police,[9] expressed that "The capacity of the police is one of the elements of the state government in the field of keeping security and public control, law implementation, assurance, safe house, and administration to the local area." In completing its capacity as cops, the police should comprehend the legitimate standards utilized as thought in doing their obligations, specifically as follows :

1. The guideline of legitimateness, Police should agree with the law in completing their obligations as law enforcers.

2. The guideline of commitment is the commitment of the police in managing optional local area issues since they have not been directed in law.

3. The rule of interest is in getting the local area climate, Police facilitate the security of Swakarsa to acknowledge legitimate consistence among the local area.

4. The rule of anticipation continually focusing on preventive measures rather than quelling (oppressive) the local area.

5. The rule of subsidiarity, doing the obligations of different offices so as not to lead to colossal issues prior to being dealt with by the office in control.

The position of the National Police is now under the President according to Article 8 of Law no. 2 of 2002 [9] states:

1. The National Police of the Republic of Indonesia is under the President.

2. The National Police of the Republic of Indonesia is led by the National Police Chief to carry out his duties is responsible to the President under the laws and regulations.

In this case, the duties and authorities of the National Police are regulated in Chapter III starting from Articles 13 to 14, which rules:

Article 13: The main tasks of the Indonesian National Police are:

1. Maintaining public security and order;

2. Enforce the law; and

3. Provide protection, protection, and service to the community. Article 14:

1. In doing the primary undertakings as alluded to in Article 13, the State Police of the Republic of Indonesia will be entrusted with : 
a. Implementing guideline, protecting, accompanying, and watching the local area and government exercises depending on the situation;

b. Organizing movements of every kind to guarantee security, request, and smooth traffic out and about;

c. Fostering the local area to build local area interest, lawful consciousness of the local area, and the dutifulness of local area individuals to laws and guidelines;

d. Participate in the improvement of public law;

e. Maintaining request and guaranteeing public security;

f. To facilitate, direct, and give specialized help to the uncommon police, government employee examiners, and different types of self-protection;

g. Conducting examinations and examinations of all criminal demonstrations keeping the criminal methodology law and different laws and guidelines;

h. Organizing police recognizable proof, police medication, measurable research facilities, and police brain science for police obligations;

i. Protecting the wellbeing of body, soul, property, society, and the climate from aggravations of request and additionally calamity, including giving help and help by maintaining basic freedoms;

j. Temporarily serve the public interest before being handled by the agency and/or the authorized party;

k. Providing administrations to the local area following their inclinations inside the extent of police obligations; just as

a) Carry out different obligations observing the laws and guidelines

2. The procedure for implementing the arrangements alluded to in section (1) letter $f$ will be additionally directed by a Government Regulation.

According to the Tribrata motto, the duties and authorities of the POLRI are: We are Indonesian Police:

a. Devote to the Homeland and the Nation with complete devotion to God Almighty.

b. Uphold truth, equity, and humankind in maintaining the laws of the Unitary State of the Republic of Indonesia dependent on Pancasila and the 1945 Constitution.

c. Always ensure, ensure and serve the local area with earnestness to make security and request.

The capacity of law requirement completed by the National Police in managing PSBB can't be isolated from its job as controlled in Law no. 2 of 2002 concerning the Police. Article 2 of this law expresses that one of the elements of the cops is the capacity of the state government in the field of keeping security and public control, law requirement, insurance, sanctuary, and administration to the local area. Unequivocally, this assertion was reaffirmed as the obligations and specialists of the National Police as controlled in Article 13 of Law no. 2 of 2002 concerning the National Police. As indicated by the past guideline, the term security with regards to the capacities and the public police work is "security and public request," in which the term has two implications. To begin with, as a unique society, as one of the necessities to do public improvement as a public objective set apart by security, request, law requirement, and security. Second, security is the capacity to reinforce and build the potential and force of the local area to forestall, forestall and beat all infringement of the law and different types of badgering that can upset general society.

During the COVID-19 pandemic, the role of the National Police is more emphasized in the second sense because, during the PSBB period, the Police carried out law enforcement functions which were reaffirmed through the Decree of the Chief of Police No. Mak/2/III/2020 concerning Compliance with Government Policies in Handling the Corona 
Virus. The announcement is an initiative of the National Police in supporting PP No. 21 of 2020 concerning PSBB and Permenkes No. 9 of 2020. The Indonesian police statement said that the national Police fully supported the government's policy on managing COVID-19 and had ended a series of riots in Indonesia by attacking the gathering.[10] In addition, the police are also committed to dealing with potential crimes by implementing PSBB, such as street crimes, fighting officers, merchandise problems, and cybercrimes. To support the enforcement aspect, the National Police held the 2020 Safe Homeland II contingency operation.

This operation was implemented from 19 March to 17 April 2020. The operation period could be extended based on the development of the situation on the ground.[11] This working group consists of many sub-organs. First, the General Crime Subs (crime) is responsible for breaking down conventional crimes (theft, theft, theft, natural disaster crimes, and quarantine health crimes). Second, the Subsatga Ekonomi is responsible for managing and destroying food storage and medical equipment, stopping the export of antiseptics, raw materials for masks, personal protective equipment (PPE) and masks, and dispensing drugs or medical equipment that do not meet standard/distribution requirements. Third, the Siberian Subsatgas has taken action against ring organizers and distributors related to the management of COVID19.

With the participation of the state and society in dealing with the COVID-19 coronavirus pandemic, which since the beginning of its spread in Indonesia has occurred since April 2020, the state has provided various policy tools in dealing with the COVID-19 coronavirus pandemic. With the enactment of Government Regulation of the Republic of Indonesia No. 21 of 2020 concerning Large-Scale Social Restrictions in the Context of Accelerating the Handling of Covid19. And the Minister of Transportation Regulation No. 25 of 2020 concerning Transportation Control During the Eid Al-Fitr Homecoming Period in $1441 \mathrm{H} \mathrm{In}$ the Context of Preventing the Spread of Covid-19, which has been progressing is proof of the government's concern in fostering public awareness to maintain health and prevent further spread. However, in practice, it is all public awareness if some do not obey and violate the rules, of course, it will harm them.

\section{Conclusion}

Following what has mandated in Law no. 2 of 2002 concerning the National Police, the National Police are part of the most important institutions at the forefront, especially in terms of handling, security as well as education and social services aimed at calming, protecting, and also providing comfort to the broader community throughout Indonesia. The duties of the Police continue to increase in line with the Covid-19 period. The National Police, which usually provides security and order, with the Covid-19 pandemic, the Police are tasked with distributing necessities to the underprivileged. Not only that, but the National Police also has other additional tasks including guarding the bodies of Covid-19, carrying out curing and burying the bodies. Even in several cases, in various regions, there were actions to refuse the bodies' burial to be done according to the Covid-19 protocol. These tasks are, of course, out of the ordinary for the Police, but they must be carried out. The Police face tougher challenges, among others, by increasing stability and legal guidance, and law enforcement in the country. On the other hand, during this Covid-19 pandemic, the National Police must also remain focused on always carrying out promoters (Modern and Trusted Professionals) by strengthening its internal ranks and also attacks from outside (External) crimes that can threaten at any time. 


\section{References}

[1] S. Soekanto, Pengantar Penelitian Hukum. Jakarta: UI Press, 2012.

[2] R. Widiyani, "Tentang New Normal di Indonesia: Arti, Fakta dan Kesiapan Daerah," detiknews, 2020. .

[3] M. Anwar, "Asimilasi dan Peningkatan Kriminalitas Di Tengah Pembatasan Sosial Berskala Besar Pandemi Corona," 'Adalah; Bul. Huk. dan Keadialan, 2020.

[4] M. Faiza, "Dampak Corona, Jumlah Pengangguran Bisa Tembus 12,7 Juta di 2021 [Impact of Corona, the Number of Unemployed Can Reach 12.7 Million in 2021 ]," kompas.com, 2020.

[5] J. K. Hukum and I. A. Millah, "Penanggulangan Kejahatan Di Masa Pandemi Covid-19 (Dalam Perspektif Kriminologi Dan Viktimologi).," J. Komun. Huk. ( JKH), vol. 6, no. 3, pp. 2356-4164., 2020.

[6] P. S. Saraswati, "Kebijakan Hukum Terhadap Penanganan Pandemi Covid-19 di Indonesia," KERTHA WICAKSANA, vol. 14, no. 2, pp. 147-152, Jul. 2020, doi: 10.22225/kw.14.2.1923.147-152.

[7] M. Abdul Kadir, "Hukum Dan Penelitian Hukum.," Bandung PT. Citra Aditya Bakti., 2015.

[8] J. Ibrahim, "Teori dan Metode Penelitian Hukum Normatif," Bayu Media, Malang, 2006.

[9] Sekretariat Negara, "Undang-Undang No. 2 Tahun 2002 tentang Polri." 2002.

[10] A. Susilo et al., "Coronavirus Disease 2019: Tinjauan Literatur Terkini," J. Penyakit Dalam Indones., vol. 7, no. 1, p. 45, Apr. 2020, doi: 10.7454/jpdi.v7i1.415.

[11] "Surat Telegram Nomor: ST/1099/IV/HUK.7.1/2020 tentang penanganan kejahatan dalam tugas ketersediaan bahan pokok dan distribusi." 2020. 